\title{
The Health Impact of Household Cooking Fuel Choice on Women: Evidence from China
}

\author{
Shu Wu
}

check for

updates

Citation: Wu, S. The Health Impact of Household Cooking Fuel Choice on Women: Evidence from China. Sustainability 2021, 13, 12080. https:/ / doi.org/10.3390/su132112080

Academic Editor: Farooq Sher

Received: 19 September 2021

Accepted: 28 October 2021

Published: 1 November 202

Publisher's Note: MDPI stays neutral with regard to jurisdictional claims in published maps and institutional affiliations.

Copyright: (C) 2021 by the author. Licensee MDPI, Basel, Switzerland. This article is an open access article distributed under the terms and conditions of the Creative Commons Attribution (CC BY) license (https:/ / creativecommons.org/licenses/by/ $4.0 /)$.
School of Economics, Zhejiang University of Finance and Economics, Hangzhou 310018, China; shu_wu@zufe.edu.cn; Tel.: +86-15267030943

\begin{abstract}
In order to achieve sustainable development, the world is experiencing a profound energy transition from traditional biomass through fossil fuel to clean and renewable energy. As women are the primary undertakers of cooking in developing countries, they are more vulnerable to household air pollution caused by solid fuel combustion. Although women can benefit from clean fuel switching for household cooking, its influence on women's health is still not well understood. Using the longitudinal data from China Family Panel Studies in 2014 and 2018, this study adopts panel data models to investigate the impact of household cooking fuel choice on women's health from multiple dimensions in China, including self-rated health, others-rated health, and instrumental activities of daily living, aiming at shedding light on energy transition and health improvement for developing countries. It is found that household cooking fuel switching from solid fuel to clean fuel improves women's self-rated and others-rated health but has no significant impact on women's abilities of independence in daily activities. Specifically, each level of household cooking fuel increases respondents' self-rated and others-rated health by 0.009 and 0.043 , respectively. Moreover, further investigation of the impact of household cooking fuel switching on the health status of women from different groups found: (1) the health effect of clean cooking fuel switching on women aged 46 and above is more significant than that on women aged 45 and below, (2) there are significant differences between urban and rural areas in the impact of household cooking fuel switching on women's health, and (3) uneducated women benefit more than educated women from clean cooking fuel switching. Finally, this study provides some policy implications to promote the energy transition and improve women's health in China and other developing countries.
\end{abstract}

Keywords: household cooking; fuel choice; health impact; women's health; instrumental activities of daily living

\section{Introduction}

Women are the principal victims among all groups influenced by energy scarcity and solid fuel-based energy consumption. Despite the ongoing clean energy transition in many developing economies, a considerable number of people still rely heavily on solid fuels for cooking. In 2018, almost 2.6 billion people, approximately $34 \%$ of the global population, continued to use biomass, coal, or kerosene as primary cooking fuels [1]. In sub-Saharan Africa, the proportion contributes to over 70\% [2]. However, cooking with solid fuels using traditional technologies often releases loads of greenhouse gases and hazardous air pollutants [3,4], which raise the probability of respiratory system disease [5], cardiovascular disease [6], cerebrovascular disease [7], blindness [8], and infant mortality [9]. Globally, household air pollution associated with solid fuel for cooking results in 2.4 million premature deaths each year [10], and 60\% of household air pollution-related death of women can be attributed to household air pollution [11].

Women are particularly vulnerable to household air pollution because they are the major undertaker of cooking activities and therefore have greater exposure to smoke [12]. Women exposed to high levels of indoor smoke are more likely to suffer from chronic obstructive pulmonary disease and lung cancer [13]. In rural areas, women's responsibilities 
are not only limited to performing cooking activities, but they are more involved in the collection and management of cooking fuels, which increases the risk of injury or violence against women $[14,15]$. Moreover, fuel gathering may take many hours and limit other productive activities. Adult women spend 50\% more time on agricultural activities than men and generally 2-5 h per day in fuel gathering [12]. In rural Africa, young women are deprived of education rights because they need to stay at home and assist their mothers with fuel collection and management [16]. Numerous studies have confirmed that women can benefit more from adopting non-solid cooking fuel $[17,18]$, while gender inequities affect household fuel choice [19].

Influenced by energy poverty and the low availability of clean fuels, solid fuels have long been an important source of household cooking fuels in China. In 2016, households using firewood and coal for cooking reached 101.77 million, constituting $44.20 \%$ of Chinese rural households [20]. The use of solid cooking fuel is associated with higher levels of indoor air pollution and health burden. It is estimated that the daily average concentration of $\mathrm{PM}_{2.5}$ in kitchens, bedrooms, and outdoors for personal exposure in the rural areas of northern China is $104 \pm 39.5,79 \pm 63.2,52.9 \pm 16.5$, and $71.7 \pm 30.8 \mu \mathrm{g} / \mathrm{m}^{3}$, respectively, which are much higher than the standard limits [21]. High exposure to household air pollutants brings a decline in health status. A nationwide prospective cohort study of 271,217 participants from rural China found that the risks of cardiovascular and all-cause mortality of adults using solid fuels for cooking increased by $20 \%$ and $11 \%$, respectively, and the risks of cardiovascular and all-cause mortality of adults using solid fuel for heating rose by 29 and 14\%, respectively [6]. Moreover, $\mathrm{PM}_{2.5}$ emissions from solid fuel combustion for cooking and heating result in the premature deaths of about 520,000 Chinese rural residents each year [22].

Likewise, Chinese women suffer most from indoor air pollution caused by solid fuel combustion because they perform most cooking activities [23]. Hence, women may benefit more from household cooking fuel switching than men [24,25], which is still not well understood in China for two reasons. First, while plenty of epidemiological and environmental literature investigates the impact of household air pollution on health in China, few studies adopt nationally representative data and a longitudinal setting. Second, some relevant studies use outdated data and draw inefficient conclusions [26]. Third, as the largest developing country, the findings and conclusions in China may shed light on the promotion of household energy transition and improvement in women's health for other developing countries relying heavily on solid fuels. Using the longitudinal data from China Family Panel Studies (CFPS) in 2014 and 2018, this study adopts panel data models to investigate the impact of household cooking fuel choice on women's health from multiple dimensions in China.

This study extends the existing literature in two ways. First, while existing literature briefly compares the impact of household cooking fuel choice on children [27], middleaged adults [23], or the elderly [24], this study focuses on the impact on the health status of women from different groups, which contributes to developing differentiated fuelswitching strategies and improving gender equality. Second, different from previous literature adopting doctors' visits and disease incidence as health outcomes, this study uses self-assessments, others' assessments, and instrumental activities of daily living (IADL) as proxies of respondents' body functionalities. As an objective indicator, IADL covers physical and mental health status and represents respondents' capacity to live independently [28]. Further, epidemiological studies have confirmed that self-assessment of health status is a reliable indicator of mortality and death risk [29,30].

The remainder of this paper is organized as follows. Section 2 provides an overview of the literature and theoretical framework. Section 3 introduces the empirical strategy and data. Section 4 reports the results and associated discussion. Section 5 ends the paper with conclusions and policy implications. 


\section{Literature Review and Theoretical Framework}

\subsection{Environmental and Health Impacts of Solid Fuel Combustions}

Biomass and coal are two primary sources of solid fuel. As solid fuel remains one of the major fuel sources for cooking and heating in developing countries, its combustion and associated environmental and health impacts have received wide attention. Biomass mainly refers to renewable organic matter derived from living organisms, such as animal wastes and agricultural and forestry residues, while coal is a carbonaceous material formed as a result of chronic coalification of dead plants [31,32]. Due to the lack of modern cooking equipment, most people in developing countries rely on traditional cooking methods such as unvented stoves and open fireplaces, which results in inefficient and incomplete combustion of solid fuel [33]. Moreover, the combustion efficiency of solid fuel is much lower than that of clean fuel [34]. As solid fuel is converted into incomplete combustion products, the concentrations of various indoor air pollutants increase significantly [35], which usually include black carbon, carbon monoxide, heavy metals, nitrous oxide, particulate matter, polycyclic aromatic hydrocarbons, sulfur dioxide, and volatile organic compounds [36,37]. These air pollutants have been commonly confirmed to be harmful to human health and induce diseases [30].

Most of the global population spends an average of $80-90 \%$ of their time indoors [33], where the space is relatively small and the air has poor mobility. Therefore, plenty of scholars have estimated indoor air pollution concentrations caused by the combustion of various solid fuels, including coal $[38,39]$ and traditional biomass energy [40]. For instance, Du et al. [41] conducted a meta-analysis of 92 studies related to indoor air pollution in China and found that outdoor, bedroom, and kitchen concentrations showed a significant increasing trend for various air pollutants. Overall, indoor concentrations of these pollutants are two to five times higher than outdoor concentrations [33]. Moreover, indoor air pollutants and toxicity mechanisms often vary across solid fuel and combustion techniques adopted [42,43]. A detailed summary of solid fuel combustion, associated air pollutants, and toxicity mechanisms can be obtained from Table 1.

Table 1. Solid fuel and its post-combustion air pollutants, toxicity mechanisms, and health impacts [33].

\begin{tabular}{|c|c|c|c|}
\hline Solid Fuel & Air Pollutants & Toxicity Mechanisms & Health Impacts \\
\hline \multirow{6}{*}{ Biomass and Coal } & $\mathrm{PM}_{2.5}, \mathrm{PM}_{10}$ & $\begin{array}{l}\text { Systemic oxidative stress and } \\
\text { inflammation }\end{array}$ & $\begin{array}{l}\text { Asthma, lung cancer, chronic obstructive } \\
\text { pulmonary disease, cough, aggravation of } \\
\text { pre-existing symptoms }\end{array}$ \\
\hline & PHAs & Carcinogenic & $\begin{array}{c}\text { Lung cancer, mouth cancer, naso-pharynx and } \\
\text { larynx cancer }\end{array}$ \\
\hline & $\mathrm{CO}$ & $\begin{array}{l}\text { Carboxy-hemoglobin production, } \\
\text { reduced oxygen delivery }\end{array}$ & $\begin{array}{l}\text { Chronic obstructive pulmonary disease } \\
\text { exacerbation, low birth weight, perinatal death }\end{array}$ \\
\hline & $\mathrm{NO}_{2}$ & $\begin{array}{l}\text { Increased bronchial reactivity and } \\
\text { susceptibility to lung infection }\end{array}$ & $\begin{array}{l}\text { Chronic obstructive pulmonary disease } \\
\text { exacerbation, low birth weight, perinatal death }\end{array}$ \\
\hline & $\mathrm{SO}_{2}$ & Increased bronchial reactivity & $\begin{array}{l}\text { Wheezing, asthma exacerbation, } \\
\text { cardiovascular disease }\end{array}$ \\
\hline & Smoke condensate & $\begin{array}{l}\text { Adsorption into lens and } \\
\text { oxidative change }\end{array}$ & Cataract, impaired vision, conjunctiva disorders \\
\hline
\end{tabular}

The threat of solid fuel combustion and associated indoor air pollution to residents' health cannot be ignored. Women and the elderly are usually the main undertakers of household cooking activities and children usually accompany their mothers or the elderly. Hence, they suffer more from indoor air pollution associated with solid fuel combustion [44,45]. Compared with clean energy, air pollution caused by solid fuel burning increases the risk of premature death and many diseases, including ocular diseases [46], respiratory diseases, lung cancer, chronic obstructive pulmonary disease, immune system hypofunction [47], lung cancer [48], hypertension and cardiovascular disease [49], and 
neonatal death and low birth weight [50]. From a subjective perspective, people often assess their health adversely when they adopt solid fuel for cooking [24]. A specific explanation of solid fuel combustion and associated health impacts is shown in Table 1.

\subsection{Environmental and Health Impacts of Clean Fuel Switching}

As local governments actively promote energy consumption transition, many scholars have evaluated the environmental and health effects of clean fuel switching. A change in cooking fuel may decrease environmental pollution [24]. Existing research on the environmental effects of clean fuel switching mainly focuses on various clean energy policies in cities, such as coal-to-gas/electricity policies [51,52] and the clean winter heating pilot project [53]. Although there are differences in research objects and methods, existing studies have found that replacing solid fuel with electricity or LPG/LNG has a relatively significant containment effect on $\mathrm{CO}_{2}, \mathrm{PM}_{2.5}, \mathrm{SO}_{2}$, and $\mathrm{NO}_{\mathrm{x}}$ emissions. For example, Chen et al. [37] conducted on-site measurement and assessment of gas and particle pollutant emissions during cooking and heating in rural households in northern China and found that replacing fuelwood and peat with briquettes and raw coal reduced the concentrations of $\mathrm{CO}, \mathrm{PM}_{10}$, and $\mathrm{PM}_{2.5}$ in the air by 28,24 , and $25 \%$, respectively. Moreover, studies from India found that switching from solid fuels such as wood to cleaner fuel such as LPG dramatically decreased personal $\mathrm{PM}_{2.5}$ exposure concentrations for cooking from $1200-1307$ to $60-83 \mu \mathrm{g} / \mathrm{m}^{3}[54,55]$.

Many scholars have evaluated the health effects of clean fuel switching. A large number of studies have shown that clean fuel switching reduces the risk of maternal mortality [56], infant mortality [57], the risk of cancer and cardiovascular disease in women [58], health risks [59], and cataracts [46], and improve the instrumental daily living activities and self-care ability of the elderly $[23,24]$. From a subjective perspective, clean fuel switching improves people's self-assessment of health status $[60,61]$. However, some scholars find that households tend to underestimate the risk of health damage from solid fuel combustion [62]. Without changing or failing to change the energy consumption structure, many scholars have made beneficial exploration on measures to improve residents' health, including using improved stoves [44], improving solid fuel quality [63], and installing range hoods [57].

\subsection{Theoretical Framework for Variable Selection}

Influenced by different research objects, different studies often adopt different health indicators. Table 2 summarizes some recent studies on the impact of fuel switching on health. Following Fang and Lu [23] and Liu et al. [24], this study adopts self-assessment of health, others-assessment of health, and IADL as proxies of respondents' health status for three reasons. First, IADL covers physical and mental health status and represents respondents' capacity to live independently [28]. Second, IADL is an objective indicator less influenced by measurement error than rough self-assessment [64]. Third, CFPS does not measure other health indicators associated with household air pollution caused by solid fuel combustion. Following the studies listed in Table 2, this study selects household income, respondent's age, household income, hukou, marriage status, number of family members, whether smoking, and whether having insurance as control variables.

Table 2. Summary of some recent studies on the impact of fuel switching on health.

\begin{tabular}{|c|c|c|}
\hline Authors & Health Indicators & Control Variables \\
\hline $\begin{array}{l}\text { Jagger and } \\
\text { Shively [5] }\end{array}$ & Acute respiratory infection & $\begin{array}{l}\text { Fuel choice, household size, age of head, female headed household, } \\
\text { education of head, ventilation, improved stove }\end{array}$ \\
\hline Nie et al. [26] & $\begin{array}{l}\text { Chronic/acute disease, fever, asthma, eye } \\
\text { disease, heart disease/chest pain, } \\
\text { self-reported health }\end{array}$ & $\begin{array}{l}\text { Cooking fuels, education levels, age, working status, household } \\
\text { size, water, flushing toilet, no excreta around the dwelling place, } \\
\text { electricity, location of health facility, distance to the health facility }\end{array}$ \\
\hline
\end{tabular}


Table 2. Cont

\begin{tabular}{|c|c|c|}
\hline Authors & Health Indicators & Control Variables \\
\hline Liu et al. [61] & $\begin{array}{l}\text { Chronic lung diseases, heart problems, } \\
\text { stroke, self-assessment of health status, }\end{array}$ & $\begin{array}{l}\text { Solid fuel, income, age, gender, smoke, drink, sleeping time, } \\
\text { kitchen, tap water, topography }\end{array}$ \\
\hline Cesur et al. [57] & Mortality rate & $\begin{array}{l}\text { Natural gas, hospital density, hospital bed density, physician } \\
\text { density, family medicine program, unemployment rate, per capita } \\
\text { GDP, vehicle density, percent high school, percent college, students } \\
\text { per teacher, governing party mayor }\end{array}$ \\
\hline Imelda [9] & Infant mortality & $\begin{array}{l}\text { Cooking fuel, mother's age, first birth, child born in the last five } \\
\text { years, antenatal visits, number of household member, television, } \\
\text { fridge, cleaning water, health facility, smoking, toilet, electricity, } \\
\text { parents' education }\end{array}$ \\
\hline $\begin{array}{l}\text { Fang and } \mathrm{Lu} \\
\text { [23] }\end{array}$ & Self-rated health, Katz index, and IADL & $\begin{array}{l}\text { Fuel switching, house type, expenditure, education, Insurance, } \\
\text { basic living allowance, smoke, marriage, gender, age, number of } \\
\text { household member, number of children, province }\end{array}$ \\
\hline Wang et al. [56] & Maternal mortality rate & $\begin{array}{l}\text { Natural gas density, hospital beds, medical staff, population with } \\
\text { maternity insurance, GDP per capita, population size, government } \\
\text { revenues per capita, population with high school degree, college } \\
\text { students, motor vehicles, temperature, precipitation }\end{array}$ \\
\hline Arku et al. [65] & $\begin{array}{l}\text { Cardiorespiratory symptoms, blood } \\
\text { pressure and hypertension, lung function, } \\
\text { and air flow obstruction }\end{array}$ & $\begin{array}{l}\text { Cooking fuel choice, education, wealth index, occupation, food } \\
\text { expenditure, gender, rural/urban, country }\end{array}$ \\
\hline Liu et al. [24] & ADL, IADL & $\begin{array}{l}\text { Cooking fuel, age, gender, education, marriage, farm work, } \\
\text { smoking, drinking, number of children, gender structure, } \\
\text { household size, house structure, assets }\end{array}$ \\
\hline $\begin{array}{l}\text { Chattopadhyay } \\
\text { et al. [66] }\end{array}$ & $\begin{array}{l}\text { Sick in last } 30 \text { days with at least one } \\
\text { physical symptom; subjective } \\
\text { probabilistic expectations variables }\end{array}$ & $\begin{array}{l}\text { Number of cooks, age, schooling year, marriage, spouse's work, } \\
\text { kitchen located inside dwelling unit, ventilation in cooking area, } \\
\text { expenditure, access to internet, television, opportunity to collect } \\
\text { cooking fuels for free }\end{array}$ \\
\hline Saenz et al. [67] & Cognitive function & $\begin{array}{l}\text { Age, gender, education, marital status, household wealth, per } \\
\text { capita consumption, region, housing status }\end{array}$ \\
\hline Tian et al. [30] & Self-rated health, chronic diseases & $\begin{array}{l}\text { Solid fuels, hukou, location, age, education, gender, jobs, smoke, } \\
\text { income, GDP per capita, population density, urbanization }\end{array}$ \\
\hline
\end{tabular}

The energy ladder theory suggests that income plays a leading role in household cooking fuel choice [68]. Rises in income levels increase the likelihood of residents replacing traditional biomass and solid fuel with clean and efficient modern energy [30], thereby improving residents' health status. Besides, plenty of studies have detected a positive impact of education on health [69]. Rises in education levels reduce the likelihood of residents using solid fuels for cooking by raising awareness of adverse health impacts or increasing the opportunity costs of poor health $[23,70]$, resulting in improved residents health status. China has a strict hukou registration system to limit rural migration to cities, maintaining the effective operation of the urban-rural dual structure [71]. Residents health status is influenced by their urban/rural identities [30]. For one thing, residents with rural hukou and those living in rural areas are more dependent on solid fuel for cooking, which increases the health risks related to solid fuel combustion. For another thing, infrastructure in urban areas is more complete than infrastructure in rural areas, including medical facilities. Hence, urban residents' health status is more guaranteed.

With the improvement of China's medical insurance system, more and more residents have medical insurance. Theoretically, medical insurance can promote the health level of the insured residents because medical insurance is a risk-sharing mechanism between healthy people and unhealthy people or between healthy people and sick people [72]. Its direct function is to ensure people's financial accessibility to medical and health services when they are sick. Hence, the insured people can obtain better medical services and are more willing to obtain medical services when they are sick. Married respondents are less likely to use non-solid fuels because they are more likely to participate in biomass collection, 
increasing their health risks of solid fuel combustion [24,73]. Moreover, respondents' age, whether smoking, and the number of family members are selected as control variables as they have been proved important factors affecting residents' health status $[23,26]$.

\section{Methodology and Data}

\subsection{Methodology}

This study employs fixed-effect models to empirically examine the impact of household fuel switching on women's health status in China. Different from conventional cross-sectional data models and time-series data models, fixed-effect models possess some advantages, such as decreasing multicollinearity among explanatory variables, allowing for heterogeneity between individuals, offering more accurate inference of model parameters, and uncovering dynamic relationships [74]. More importantly, fixed-effect models can control for missing variables that are consistent over time, including health perception, risk appetite, and other heterogeneity at the levels of individuals, households, communities, or regions in this study. Following Fang and Lu [23], this study adopts the following fixed-effect model:

$$
\text { Health }_{i t}=\beta_{1}+\beta_{2} F C_{i t}+\beta_{3} X_{i t}+\delta_{i}+\varepsilon_{i t}
$$

In Equation (1), Health ${ }_{i t}$ represents the health status of the respondent $i$ in the year $t$, which is a proxy of three health indicators including the self-ratings of health status, interviewers' assessment of respondents' health, and IADL. $F C_{i t}$ represents the respondent i's fuel choice in the year $t$, which is an ordered variable. $X_{i t}$ are controlled variables that may influence a respondent's health, including age, household income, hukou, marriage status, the number of family member, whether smoking, and whether having insurance. $\delta_{i}$ is the province fixed effect and $\varepsilon_{i t}$ represents the random error item. The coefficient $\beta_{2}$ measures the change in a respondent's health status corresponding to the change in household fuel choice.

In addition, extensive empirical studies reveal that solid fuel combustion and associated household indoor air pollution have different health impacts on women from different groups $[23,26]$. Specifically, this study classifies respondents according to their age, hukou, and education. The following fixed-effect model is adopted to further investigate the health impact of household fuel switching on women from different groups:

$$
\text { Health }_{i t g}=\beta_{1}+\beta_{2} F C_{i t g}+\beta_{3} X_{i t g}+\delta_{i}+\lambda_{t}+\varepsilon_{i t}
$$

In Equation (2), the subscript $g$ represents the age, education, and hukou groups to which a respondent belongs to. Health $h_{\text {itg }}$ represents the health status of the respondent $i$ from group $g$ in the year $t . F C_{i t g}$ represents the fuel choice and $X_{i t}$ are controlled variables of the respondent $i$ from group $g$ in the year $t$, including age, household income, hukou, marriage status, the number of family member, whether smoking, and whether having insurance.

\subsection{Data}

CFPS is a nationally representative, biannual longitudinal survey of Chinese communities, families, and individuals launched in 2010 by the Institute of Social Science Survey of Peking University, China [75]. The CFPS is designed to collect individual-level, family-level, and community-level longitudinal data in contemporary China. The studies focus on Chinese residents' economic and non-economic well-being and a wide range of research topics, including economic activities, education outcomes, family relationships and dynamics, population migration, and health. The CFPS sample covers 25 provinces, municipalities, and autonomous regions, with a target sample size of 16,000 households, and all members of the sample households are included in the survey. The studies have published six batches of data, including 2010, 2011, 2012, 2014, 2016, and 2018. This study adopts the data in 2014 and 2018 as research samples for two reasons. Firstly, the period is long enough to observe the impact of the household cooking fuel switching on women's 
health status. Secondly, using recent data helps obtain timely and effective conclusions, which are the basis for practical policy recommendations. After deleting some samples due to severe data missing, this study contains 5180 samples from 25 Chinese provinces in 2014 and 2018 (see Figure 1).

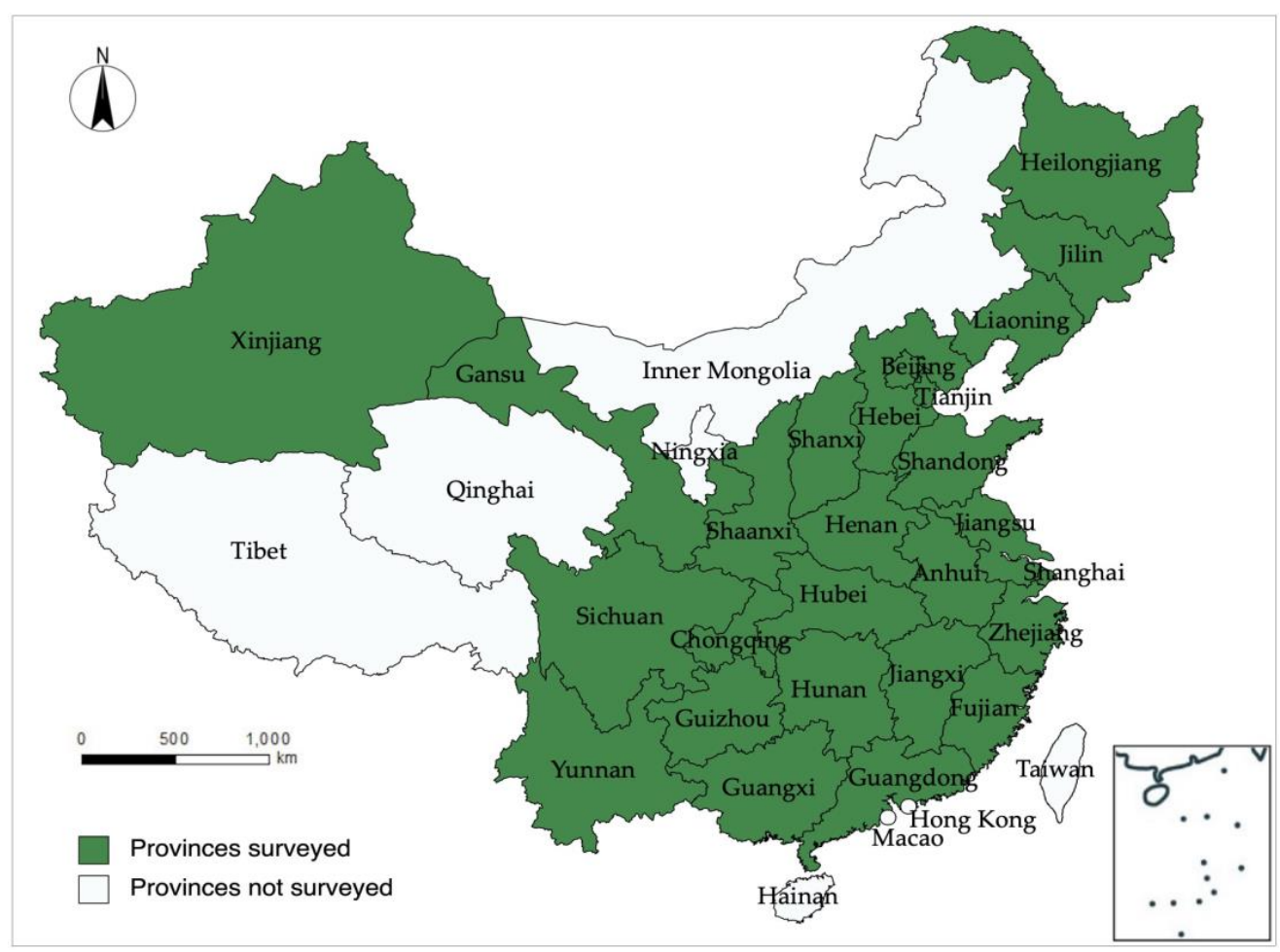

Figure 1. Distribution of provinces surveyed and not surveyed in CFPS in 2014 and 2018 [75].

Regarding the data used in this study, some points deserve special attention. First, this study adopts three indicators to depict respondents' health status, including selfrated health status, others-rated health status, and IADL. The combination of subjective and objective indicators can give a more comprehensive picture of the health status of respondents. Self-rated health status is a dummy variable, while others-rated health status and IADL are ordered variables. For the last two variables, the higher the score, the healthier the respondents are. IADL measures people's ability to cope with daily activities related to independent living, such as cooking, housekeeping, and shopping. Seven IADL are used and respondents are asked whether they could fulfill the task (see Table A1). Second, people's medical insurance varies depending on their hukou and jobs in China. Specifically, the medical insurance in the CFPS includes new-type rural cooperative medical insurance, public health services, medical insurance for urban workers, medical insurance for urban residents, and supplementary medical insurance. This study assigns a value of 1 to respondents with insurance, regardless of the type of insurance. Third, fuel choice is also an ordered variable, which is assigned according to their cleanliness. Fourth, this study adopts the logarithmic form of household income. Finally, smoking indicates whether the respondent has smoked in the past month.

Table 3 shows the summary statistics of the data. The average levels of respondents self-rated health, other-rated health, and IADL are $0.8,5.4$, and 6.83 , respectively, which demonstrates a relatively high level of respondents' health status. Besides, the average score of respondents' fuel choice is 2.74, which implies that respondents' households still rely heavily on solid fuels, including biomass and coal. Moreover, Table 3 reveals that most respondents are middle-aged and elderly, married, living in rural areas, literate, having insurance, and do not smoke. 
Table 3. Summary statistics for dependent variables, key explanatory variables, and control variables.

\begin{tabular}{|c|c|c|c|c|c|}
\hline Variable & Definition & Mean & Std. & Min. & Max. \\
\hline Self-rated & Respondents' self-rated health status $(1=$ Health; $0=$ Poor health $)$ & 0.80 & 0.40 & 0 & 1 \\
\hline Others-rated & Investigators' evaluation of respondents' health status (1-7) & 5.40 & 1.30 & 1 & 7 \\
\hline IADL & Investigators' instrumental activities of daily living $(0-7)$ & 6.83 & 0.72 & 0 & 7 \\
\hline Fuel & Fuel switching $(1=$ Biomass $; 2=$ Coal $; 3=$ LPG $/$ LNG $4=$ Solar energy $/$ Biogas $; 5=$ Electricity $)$ & 2.74 & 1.61 & 1 & 5 \\
\hline Income & Annual income of a household (ogarithmic) & 11.18 & 12.03 & 0 & 15.53 \\
\hline Age & Age of the respondent & 49.87 & 14.50 & 16 & 92 \\
\hline Marriage & Whether married or not $(1=$ Yes; $0=$ No $)$ & 0.87 & 0.34 & 0 & 1 \\
\hline Hukou & China's household registration system $(1=$ Urban; $0=$ Rural $)$ & 0.27 & 0.45 & 0 & 1 \\
\hline Education & $\begin{array}{c}\text { Education years }(0=\text { Illiterate } / \text { Semiliterate } ;=\text { Elementary school; } 9=\text { Junior high school; } \\
\qquad 12 \text { = Senior high school/Technical school } / \text { Technical school } / \text { Vocational high school; } \\
\qquad 15=\text { Junior college; } 16 \text { = Undergraduate; } 18 \text { = Graduate })\end{array}$ & 5.82 & 5.11 & 0 & 18 \\
\hline Insurance & $(1=$ Having insurance; $0=$ No insurance $)$ & 0.93 & 0.25 & 0 & 1 \\
\hline Smoke & $(1=$ Smoking; $0=$ No smoking $)$ & 0.03 & 0.18 & 0 & 1 \\
\hline Member & The number of family members & 4.27 & 1.97 & 1 & 21 \\
\hline
\end{tabular}

Data source: CFPS [75].

\section{Results and Discussion}

\subsection{The Results for Descriptive Statistics}

The proportions of different fuels for household cooking have changed significantly from 2014 to 2018 (see Figure 2). Specifically, the share of households using biomass and coal decreased from 42.37 and 8.03 to 32.05 and 5.15\%, respectively, implying that households relying on solid fuels decreased from 50.40 to $37.20 \%$. In contrast, remarkable growth has been witnessed in the share of households using non-solid fuels. The share of rural households using LPG/LNG and electricity increased from 27.99 and 20.68 to 28.32 and $33.78 \%$, respectively, which indicates that the share of households adopting non-solid fuels increased from 48.67 to $62.10 \%$. Under the pressure of environmental protection and sustainable development, energy transition towards cleaner and more efficient fuels have been proposed by the Chinese government as an integrated component of a clean energy strategy [68]. Overall, the cleanliness of household cooking fuel has been improved in China. This finding is consistent with some empirical results $[23,24]$ that Chinese rural households rely heavily on solid fuels for cooking, but the proportion of clean fuels has been improved.

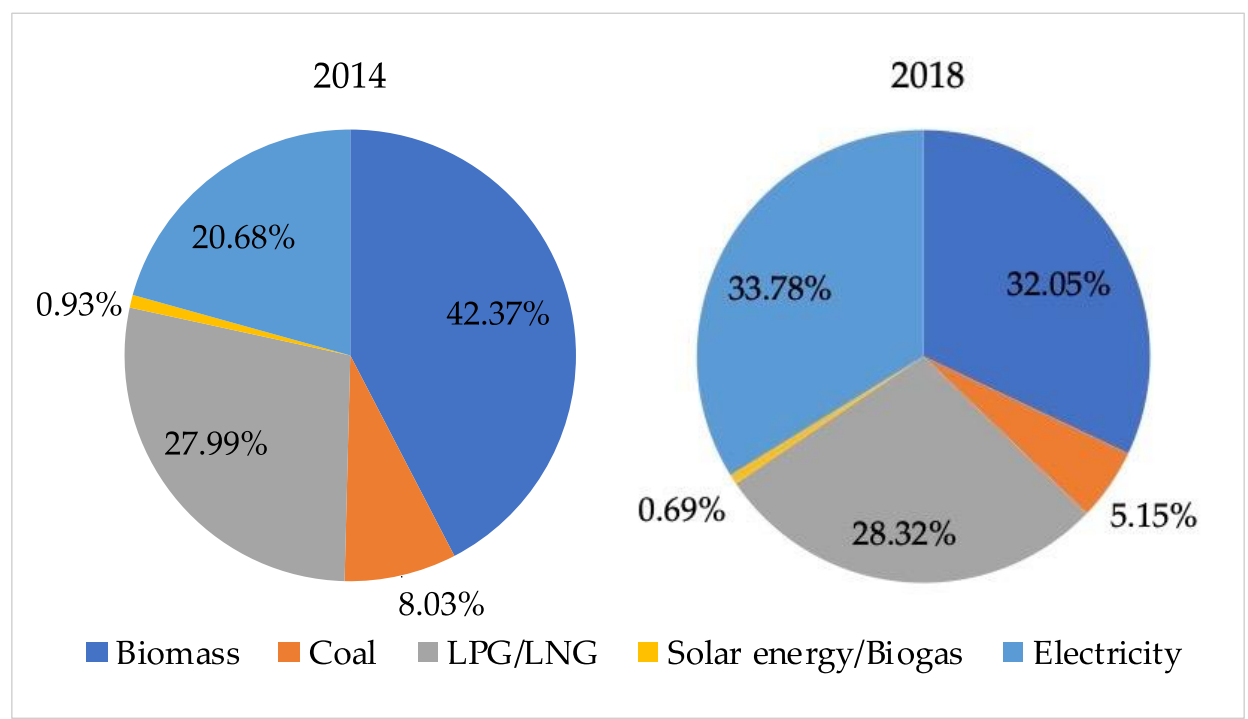

Figure 2. The structure of household cooking fuels in 2014 and 2018.

The number of respondents with different self-rated scores in 2014 and 2018 is displayed in Figure 3. The number of respondents who rated their health status as healthy increased from 3888 in 2014 to 4402 in 2018, while the number of respondents who rated 
their health status as unhealthy decreased from 1292 to 778 . The overall health status of the sample improved in the investigation period.

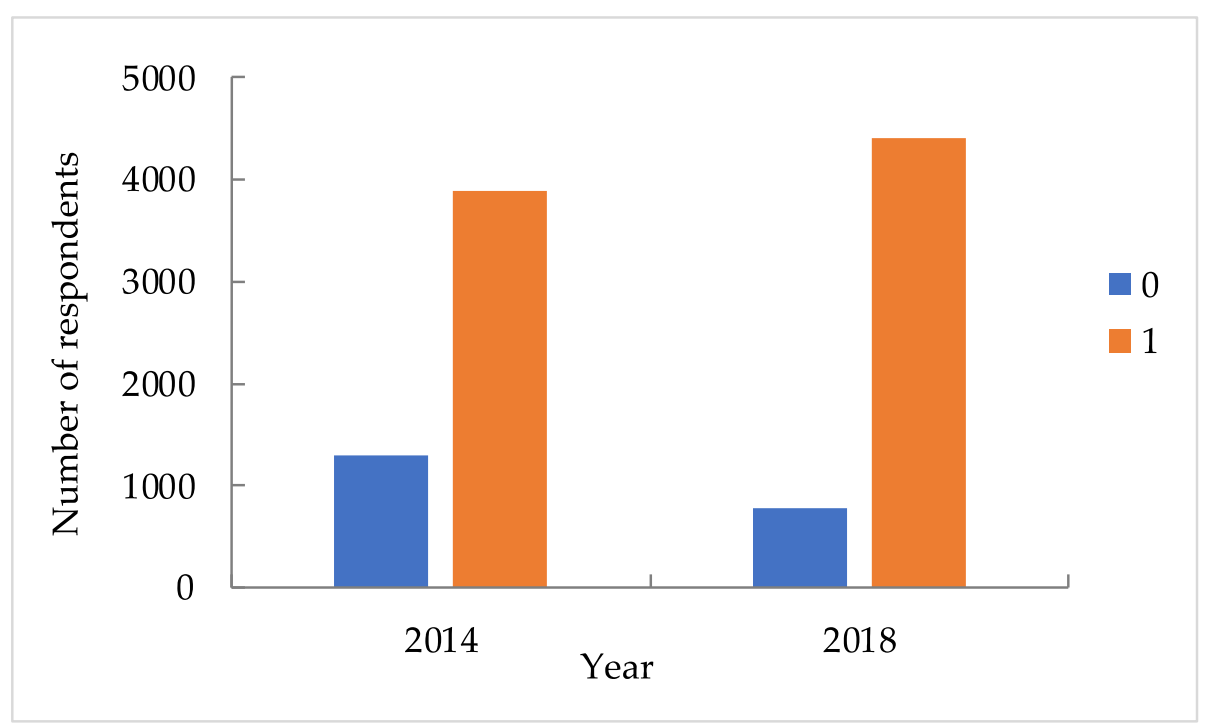

Figure 3. The number of respondents with different self-rated scores $(1=$ Health; $0=$ Poor health $)$ in 2014 and 2018.

The number of respondents with different others-rated scores in 2014 and 2018 is displayed in Figure 4. The number of respondents with others-rated scores of 1, 2, 3, and 7 increased from 24, 80, 218, and 1057 in 2014 to 58, 118, 331, and 1273 in 2018, while the number of respondents with others-rated scores of 4, 5, and 6 decreased from 747, 1401, and 1653 to 734,1308 , and 1358. The overall health status of the sample declined in the investigation period.

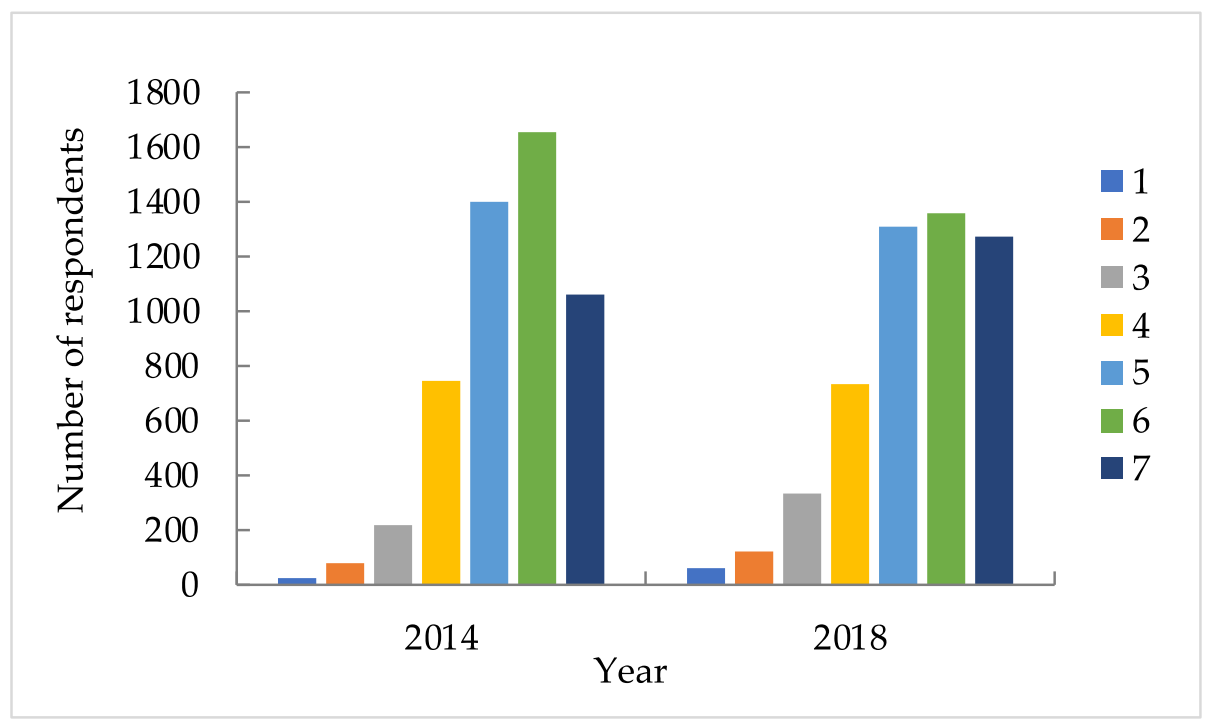

Figure 4. The number of respondents with different others-rated scores (1-7, the higher, the healthier) in 2014 and 2018.

The number of respondents with different IADL scores in 2014 and 2018 is displayed in Figure 5. The number of respondents with IADL scores of 0, 1, 2, 3, 4, 5, and 6 increased from 5, 14, 11, 11, 28, 54, and 156 in 2014 to 10, 30, 22, 26, 42, 129, and 344 in 2018, while the number of respondents with IADL scores of 7 decreased from 4901 to 4577 . Moreover, the overall health status of the sample declined in the investigation period. 


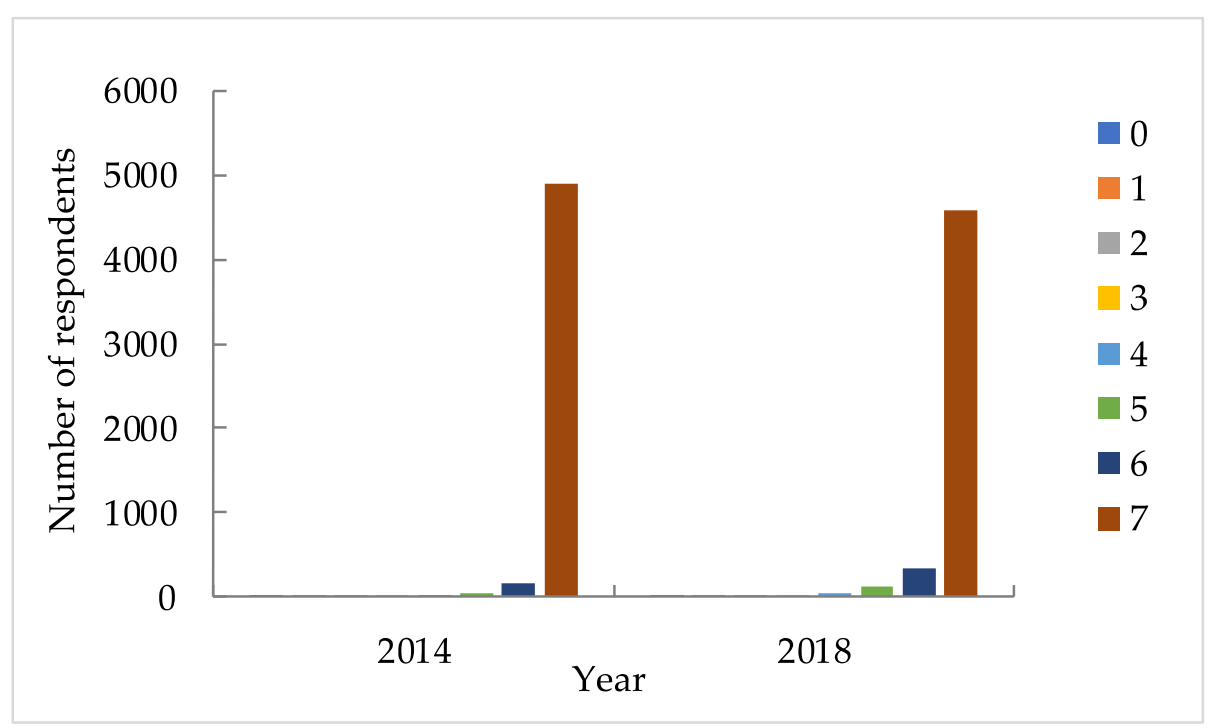

Figure 5. The number of respondents with different IADL scores (0-7, the higher, the healthier) in 2014 and 2018.

\subsection{The Results for Econometric Analysis}

\subsubsection{The Impact of Fuel Switching on the Women's Health}

The estimation results are reported in Table 4. Columns (1)-(6) summarize the estimation results of Equation (1): as a baseline reference, Columns (1)-(3) are the regression results based on the method of pooled ordinary least squares (POLS), which employs fuel choice as regressors with robust standard errors clustered at the province level. However, when heteroscedasticity exists, the parameters estimated by POLS are linear and unbiased but inefficient. Contemporaneous correlation may exist when the stochastic disturbances of different groups interact with each other. Moreover, when missing important explanatory variables, setting models improperly, existing random interference factors and autocorrelation will appear, leading to inaccurate estimation of parameters and inefficiency of POLS [76]. Hence, Columns (4)-(6) give the result of the fixed-effect regression with consideration of province fixed effects. A fixed-effect model hypothesizes that the residuals composed of unobservable regional effects are related to independent variables. In contrast, a random-effect model hypothesizes that the residuals composed of unobservable regional effects are randomly distributed and strictly independent of independent variables [76].

Consistent with most previous studies $[23,26]$, clean switching of cooking fuel has a positive impact on women's health. Specifically, household cooking fuel switching from solid fuel to clean fuel improves women's self-rated health and others-rated health, which are significant at the $1 \%$ level. Women who spend a considerable portion of their time indoors engage in household activities such as cooking and cleaning, which implies that they are particularly more vulnerable to diseases caused by indoor air pollution from solid fuel combustion [23]. For instance, research on the health level of housewives in Shanghai suburbs shows that the average daily exposure concentration of $\mathrm{PM}_{2.5}$ of homemakers is generally higher than the outdoor peripheral level, and indoor mixed pollutants such as coal and fuel oil are the main sources [77]. Hence, women's health risks related to solid fuels in the cooking process are reduced when substituting solid fuel with clean fuel, thereby improving their self-rated health and others-rated health.

However, the impact of household cooking fuel switching on IADL is insignificant, which implies that clean cooking fuel switching does not significantly influence women's ability to cope with daily activities. This may be attributed to the following reasons. IADL only assesses respondents' body functionalities relating to abilities or independence in daily activities, which may not be directly related to the adverse health impacts of solid fuel combustion. For instance, IADL measures respondents' independence in doing outdoor activities, eating, kitchen activities, using public transportation, shopping, cleaning, and 
doing laundry, which is not directly influenced by household indoor air pollution from solid fuel combustion. More importantly, IADL is more suitable for measuring the elderly's health status while the respondents in this study are middle-aged women. The results show the situation of women's health and energy transition in rural China.

Table 4. The empirical results for the impact of household cooking fuel choices on the health status of women.

\begin{tabular}{|c|c|c|c|c|c|c|}
\hline & \multicolumn{3}{|c|}{ POLS } & \multicolumn{3}{|c|}{ FE } \\
\hline & (1) & (2) & (3) & (4) & (5) & (6) \\
\hline & Self-Rated & Others-Rated & IADL & Self-Rated & Others-Rated & IADL \\
\hline Fuel & $\begin{array}{c}0.0241^{* * *} \\
(10.03)\end{array}$ & $\begin{array}{c}0.0284^{* * *} \\
(3.71)\end{array}$ & $\begin{array}{c}0.0118 * * \\
(2.68)\end{array}$ & $\begin{array}{c}0.00854 \text { ** } \\
(2.72)\end{array}$ & $\begin{array}{c}0.0431^{* *} \\
(2.62)\end{array}$ & $\begin{array}{c}-0.00414 \\
(-0.49)\end{array}$ \\
\hline Income & $\begin{array}{c}0.0160 * * * \\
(7.84)\end{array}$ & $\begin{array}{c}0.0398^{* * *} \\
(6.12)\end{array}$ & $\begin{array}{c}0.0000657 \\
(0.02)\end{array}$ & $\begin{array}{c}0.00361 * \\
(2.02)\end{array}$ & $\begin{array}{c}0.0376^{* * *} \\
(4.02)\end{array}$ & $\begin{array}{c}-0.00107 \\
(-0.22)\end{array}$ \\
\hline Age & $\begin{array}{c}-0.00469^{* * *} \\
(-15.50)\end{array}$ & $\begin{array}{c}-0.0213^{* * *} \\
(-22.06)\end{array}$ & $\begin{array}{c}-0.0110^{* * *} \\
(-19.76)\end{array}$ & $\begin{array}{c}0.0232^{* * *} \\
(19.16)\end{array}$ & $\begin{array}{c}-0.0292^{* * *} \\
(-4.61)\end{array}$ & $\begin{aligned}- & 0.0302 * * * * \\
& (-9.20)\end{aligned}$ \\
\hline Marriage & $\begin{array}{c}0.00195 \\
(0.18)\end{array}$ & $\begin{array}{c}0.0710 * \\
(2.01)\end{array}$ & $\begin{array}{c}0.148^{* * *} \\
(7.34)\end{array}$ & $\begin{array}{c}-0.0403 * \\
(-2.19)\end{array}$ & $\begin{array}{c}0.0573 \\
(0.60)\end{array}$ & $\begin{array}{c}0.142^{* *} \\
(2.85)\end{array}$ \\
\hline Hukou & $\begin{array}{c}0.0277^{* *} \\
(2.80)\end{array}$ & $\begin{array}{c}0.108^{* * *} \\
(3.42)\end{array}$ & $\begin{array}{c}0.0571^{* *} \\
(3.14)\end{array}$ & $\begin{array}{c}0.00672 \\
(0.29)\end{array}$ & $\begin{array}{l}-0.298^{*} \\
(-2.47)\end{array}$ & $\begin{array}{l}-0.0607 \\
(-0.98)\end{array}$ \\
\hline Education & $\begin{array}{c}0.0119 * * * \\
(12.69)\end{array}$ & $\begin{array}{c}0.0457^{* * *} \\
(15.22)\end{array}$ & $\begin{array}{c}0.00897^{* * *} \\
(5.21)\end{array}$ & $\begin{array}{c}-0.00760 * * \\
(-2.73)\end{array}$ & $\begin{array}{c}-0.00933 \\
(-0.64)\end{array}$ & $\begin{array}{c}0.0142 \\
(1.89)\end{array}$ \\
\hline Insurance & $\begin{array}{c}-0.00834 \\
(-0.56)\end{array}$ & $\begin{array}{c}0.0763 \\
(1.61)\end{array}$ & $\begin{array}{c}0.0689 * \\
(2.53)\end{array}$ & $\begin{array}{l}-0.0208 \\
(-1.58)\end{array}$ & $\begin{array}{l}0.123 \\
(1.80)\end{array}$ & $\begin{array}{c}0.0424 \\
(1.20)\end{array}$ \\
\hline Smoke & $\begin{array}{c}-0.0540 * * \\
(-2.65)\end{array}$ & $\begin{array}{l}0.125 \\
(1.91)\end{array}$ & $\begin{array}{c}-0.0855^{*} \\
(-2.29)\end{array}$ & $\begin{array}{l}-0.0128 \\
(-0.41)\end{array}$ & $\begin{array}{l}0.235 \\
(1.43)\end{array}$ & $\begin{array}{l}-0.0557 \\
(-0.66)\end{array}$ \\
\hline Member & $\begin{array}{c}0.00908^{* * *} \\
(4.49)\end{array}$ & $\begin{array}{l}-0.0112 \\
(-1.74)\end{array}$ & $\begin{array}{c}-0.00284 \\
(-0.77)\end{array}$ & $\begin{array}{c}-0.00446 \\
(-1.55)\end{array}$ & $\begin{array}{c}-0.00763 \\
(-0.51)\end{array}$ & $\begin{array}{c}0.0119 \\
(1.53)\end{array}$ \\
\hline $\mathrm{R}^{2}$ & 0.1223 & 0.1472 & 0.0788 & 0.1037 & 0.0086 & 0.0255 \\
\hline Region fixed & No & No & No & Yes & Yes & Yes \\
\hline Constant & $\begin{array}{l}0.695^{* * *} \\
(22.17)\end{array}$ & $\begin{array}{l}5.591 * * * \\
(55.80)\end{array}$ & $\begin{array}{l}7.098^{* * *} \\
(123.59)\end{array}$ & $\begin{array}{c}-0.302 * * * \\
(-5.15)\end{array}$ & $\begin{array}{c}6.349^{* * *} \\
(20.64)\end{array}$ & $\begin{array}{c}8.080^{* * * *} \\
(50.82)\end{array}$ \\
\hline Observation & 10,360 & 10,360 & 10,360 & 10,360 & 10,360 & 10,360 \\
\hline
\end{tabular}

Note: $t$ statistics in parentheses. ${ }^{*} p<0.05,{ }^{* *} p<0.01,{ }^{* * *} p<0.001$.

From the perspective of women's health, with the trend of feminization of agriculture, empty rural areas, and aging society, women have become the mainstay of rural development and construction in China. The healthy poverty level of women is crucial to the development of family and society, especially in ethnic minority areas and areas with deep poverty. Rural women are vulnerable to health risks, resulting in health deprivation and loss of health opportunities and presenting fragile states of health vulnerability, economic vulnerability, and social vulnerability [78]. In family and social development, rural women find it difficult to obtain stable economic income, a lack of social and family rights, and a lack of social capital stock, which makes it difficult for poor women to improve the poverty situation. In rural areas, the lack of medical resources, weak awareness of disease prevention and control, poor natural environment, and other overlapping phenomena are common. In addition, rural women bear multiple responsibilities, such as taking care of families, supporting the elderly, and assuming labor services, making rural women a high incidence of health and poverty [79]. Hence, women are still the major victims of solid fuel combustion.

At present, there are differences in academic circles on the path of China's rural energy transition. Some scholars believe that China's rural energy consumption is still dominated by straw, firewood and animal manure, and other biomass fuels, which is mainly facing the transition from traditional biomass energy to traditional commodity energy or new commodity energy [80]. However, some other scholars think that China's rural energy consumption is dominated by traditional commodity energy and faces a double transition from biomass to traditional commodity energy and from traditional commodity 
energy to new commodity energy [81,82]. Despite the rural energy transition status, the Chinese government has detected the impact of solid fuel combustion on rural residents' health status. For instance, the Energy Production and Consumption Revolution Strategy (2016-2030) and Healthy China Action (2019-2030) proposed improving the proportion of clean energy such as electricity and solar energy to reduce the negative impact of solid fuel on residents' health.

Household income has a significantly positive impact on women's health status, which is consistent with existing literature $[23,30]$. The underlying explanation is that residents with higher incomes have access to cleaner energy and cooking facilities, better medical care, and healthier food, thereby improving residents' health status. Besides, women's age negatively affects their health status, which is consistent with shared knowledge that as people age, their health status declines [24]. As for marriage, empirical results reveal that married women tend to have a better health status, which is similar to the finding of Liu et al. [24]. Some potential explanations are that married people can share the cost for household cooking fuel use. Hukou has a significantly positive impact on women's health status, which is consistent with Tian et al. [30]. There are two causes. First, residents with rural hukou and those living in rural areas are more dependent on solid fuel for cooking. Second, urban areas' infrastructure is more complete than rural areas, including medical facilities. Hence, urban residents' health status is more guaranteed. Numerous studies have found a positive impact of education on health [69], which is also proven by this study. With the improvement of education level, residents are less likely to use solid fuels for cooking by raising awareness of adverse health impacts or increasing the opportunity costs of poor health $[23,70]$.

\subsubsection{The Impact of Household Cooking Fuel Choices on the Health of Women of Different Groups}

This study further examines the health effects of clean cooking fuel switching on women from different age groups, region groups, and education groups. The estimation results are reported in Table 5. Similarly, Columns (1)-(6) summarize the results of estimation of Equation (2): as a baseline reference, Columns (1)-(3) are the regression results based on the method of pooled OLS, and Columns (4)-(6) give the result of the fixed-effect regression with consideration of both province fixed effects. Besides, to save the article length, control variables are not reported in Table 5.

Table 5. The empirical results for the impact of household cooking fuel choices on the health status of women from different groups.

\begin{tabular}{|c|c|c|c|c|c|c|}
\hline & \multicolumn{3}{|c|}{ POLS } & \multicolumn{3}{|c|}{ FE } \\
\hline & (1) & (2) & (3) & (4) & (5) & (6) \\
\hline & Self-Rated & Others-Rated & Rated & Self-Rated & Others-Rated & Rated \\
\hline $45 \leq$ & $\begin{array}{c}0.0118^{* * *} \\
(4.62)\end{array}$ & $\begin{array}{c}0.00924 \\
(0.89)\end{array}$ & $\begin{array}{c}-0.00223 \\
(-1.47)\end{array}$ & $\begin{array}{c}0.0160^{* * *} \\
(5.12)\end{array}$ & $\begin{array}{c}0.00319 \\
(0.15)\end{array}$ & $\begin{array}{c}-0.00346 \\
(-1.08)\end{array}$ \\
\hline $46 \geq$ & $\begin{array}{c}0.0307^{* * *} \\
(8.23)\end{array}$ & $\begin{array}{c}0.0405^{* * *} \\
(3.64)\end{array}$ & $\begin{array}{c}0.0209 * * \\
(2.70)\end{array}$ & $\begin{array}{c}0.0357^{* * * *} \\
(7.25)\end{array}$ & $\begin{array}{c}0.0354 \\
(1.58)\end{array}$ & $\begin{array}{c}-0.0470 \text { ** } \\
(-3.29)\end{array}$ \\
\hline Rural & $\begin{array}{c}0.0273^{* * *} \\
(9.93)\end{array}$ & $\begin{array}{c}0.0394^{* * *} \\
(4.60)\end{array}$ & $\begin{array}{c}0.0163^{* *} \\
(3.24)\end{array}$ & $\begin{array}{c}0.00387 \\
(1.06)\end{array}$ & $\begin{array}{c}0.0481 * \\
(2.54)\end{array}$ & $\begin{array}{c}0.000769 \\
(0.08)\end{array}$ \\
\hline Urban & $\begin{array}{c}0.00388 \\
(0.72)\end{array}$ & $\begin{array}{l}-0.0173 \\
(-0.91)\end{array}$ & $\begin{array}{c}-0.0198 * \\
(-1.99)\end{array}$ & $\begin{array}{c}0.0219 * * \\
(3.28)\end{array}$ & $\begin{array}{c}0.00435 \\
(0.12)\end{array}$ & $\begin{array}{c}-0.00364 \\
(-0.20)\end{array}$ \\
\hline Uneducated & $\begin{array}{c}0.0343^{* * * *} \\
(7.28)\end{array}$ & $\begin{array}{c}0.0547^{* * *} \\
(4.00)\end{array}$ & $\begin{array}{c}0.0209^{*} \\
(2.14)\end{array}$ & $\begin{array}{c}0.00539 \\
(0.91)\end{array}$ & $\begin{array}{c}0.0704 \text { * } \\
(2.52)\end{array}$ & $\begin{array}{c}-0.00626 \\
(-0.34)\end{array}$ \\
\hline Educated & $\begin{array}{c}0.0162^{* * * *} \\
(6.28)\end{array}$ & $\begin{array}{c}0.0180 \text { * } \\
(1.96)\end{array}$ & $\begin{array}{c}0.00623 \\
(1.69)\end{array}$ & $\begin{array}{c}0.00654 \\
(1.86)\end{array}$ & $\begin{array}{c}0.0276 \\
(1.35)\end{array}$ & $\begin{array}{c}0.00777 \\
(1.06)\end{array}$ \\
\hline Region fixed & No & No & No & Yes & Yes & Yes \\
\hline
\end{tabular}

Note: (1) $t$ statistics in parentheses, ${ }^{*} p<0.05,{ }^{* *} p<0.01,{ }^{* * *} p<0.001 ;(2)$ in this table, control variables are not reported. 
From the perspective of different age groups, women from two age groups benefit from clean cooking fuel switching, and the health effect of clean cooking fuel switching on women aged 46 and above is more significant than that on women aged 45 and below. The empirical result is inconsistent with Song and $\mathrm{Li}$ [25]. For instance, Song and $\mathrm{Li}$ [25] find that the physical and mental health of young and middle-aged rural residents between 18 and 60 years old has been improved due to clean fuel switching, while the physical and mental health of rural residents over the age of 60 has not been significantly improved. The difference may be attributed to different research objects selected in this study and Song and Li [25]. More importantly, as people age, their health status declines [24]. Compared with women aged 45 and below, women aged 46 and above are exposed to solid cooking fuels for a longer period and are more vulnerable to household air pollution caused by solid fuel combustion. Hence, clean household fuel switching has a more significant impact on women aged 46 and above than women aged 45 and below.

Many previous studies adopt samples of rural residents when examining the health effects of residents' cooking fuel choices in China, which presuppose the existence of urban-rural inequality $[24,60]$. However, the literature lacks a thorough investigation of respondents' urban-rural identity and is inefficient in identifying urban-rural energy inequity. From the angle of different region groups, the health effect of clean cooking fuel switching on women from rural areas is significant, while that on women from urban areas is insignificant or even negative, which may be attributed to the following reasons. For one thing, the proportion of rural residents who feel unhealthy and suffer from chronic diseases is much higher than that of rural residents, and solid fuel use for household cooking increases health discrepancies between urban and rural residents [30]. Besides, the process of household cooking fuel switching in rural areas falls behind that in urban areas in China [70,83], which results in different household cooking fuel patterns and associated women's health issues. Consequently, women in rural areas can benefit more from household cooking fuel switching to clean fuels than women in urban areas.

The measurement error of income and consumption is significant, while the measurement error of education level is negligible. Therefore, this study takes education level as the basic index to measure respondents' social and economic status. Specifically, although household cooking fuel switching improves the self-rated health and others-rated health of both educated and uneducated women, uneducated women benefit more than educated women as their coefficients are greater. The empirical results are consistent with Fang and $\mathrm{Lu}$ [23], that women with lower levels of education obtain higher health returns from household cooking fuel switching. The underlying explanation may be that compared with illiterate women, non-illiterate women have lower overall health risks, are more likely to install range hoods and chimneys before energy substitution, have better kitchen ventilation, and are less exposed to solid fuels, leading to less marginal health benefits from household cooking fuel switching. However, the result is contrary to Song and Li [25], that illiteracy does not affect the health improvement effect of living energy. In other words, rural residents do not make a rational choice of living fuel and healthy lifestyle depending on the active guidance of the government and public opinion. The difference may be attributed to the difference in study objects as the object in this study is women, while Song and $\mathrm{Li}$ [25] consider both men and women.

\subsubsection{Policy Implications}

The above findings provide some policy implications for designing and implementing integrated energy and health policies for China and other developing countries. First, more attention should be paid to women's health as they are the principal undertakers of household cooking and major sufferers of household indoor air pollution, while it is difficult for them to obtain stable economic income, social and family rights, and social capital stock. Specific measures include subsidies for low-income households to improve house ventilation and purchase advanced cooking equipment and publicity measures to advocate sharing household cooking among family members. Second, it is suggested 
that governments should promote knowledge of the energy transition and the health impacts of solid fuels. The empirical result reveals that rises in education levels reduce the likelihood of residents using solid fuels for cooking by raising awareness of negative health impacts or increasing the opportunity costs of poor health. Some specific measures include combining the adjustment of energy structure with the construction of healthy countryside, emphasizing the environmental health hazards of solid fuel in the publicity of healthy environment, health knowledge, and healthy behavior, and stimulating the consciousness and initiative of rural residents to substitute energy for daily life. Third, it is suggested to combine energy substitution with targeted poverty alleviation. Poverty due to disease is one of the most severe challenges facing China's poverty alleviation strategy. Due to poverty, many residents are relatively vulnerable and rely more on traditional solid fuels, thus suffering higher health risks and falling into the poverty trap due to the energy structure. Therefore, subsidies can be provided for poor and low-income residents to use cleaner energy, such as natural gas, fuel, and biogas, to implement targeted poverty alleviation strategies. Fourth, it is suggested to further clarify the strategy for improving the energy mix, strengthen the construction of energy infrastructure networks in villages with convenient transportation and high density of rural residents, and promote the extension of gas supply facilities to rural areas in light of transportation and village settlement conditions. In rural areas where transportation is inadequate and farmers live scattered, biogas, solar energy, solar power, and wind power should be vigorously developed.

\section{Conclusions}

The Chinese government is actively promoting the energy transition from solid fuel to modern and clean energy in the living sector. An important policy goal is to reduce the health risks caused by air pollution. However, influenced by China's coal-based and biomass-based energy production and consumption structure, solid fuel is still an essential energy source for household cooking and heating which poses an enormous threat to residents' health. As women are primary undertakers of cooking activities in China, they have greater exposure to the smoke related to solid fuel combustion for cooking and suffer more from associated health issues. Using the longitudinal data from China Family Panel Studies (CFPS) in 2014 and 2018, this study adopts panel data models to investigate the impact of household cooking fuel switching on women's health from multiple dimensions in China, aiming at shedding light on energy transition and health improvement for some other developing and underdeveloped countries. Based on the empirical results, this study draws the following conclusions.

First, household cooking fuel switching from solid fuels to clean fuels improves women's self-rated health and others-rated health. Specifically, each level of household cooking fuel increases respondents' self-rated and others-rated health by 0.009 and 0.043 , respectively. This may be attributed to the fact that the two indicators comprehensively measure respondents' health status. Women's health risks related to solid fuels in the cooking process are reduced when substituting solid fuel with clean fuel. Besides, household cooking fuel switching from solid fuels to clean fuels improves women's self-rated health and others-rated health but has no significant impact on women's abilities of independence in daily activities. This may be attributed to the fact that IADL only assesses respondents' body functionalities relating to abilities or independence in daily activities that are not be directly related to the adverse health impacts of solid fuel combustion. In addition, IADL is more suitable for measuring the elderly's health status while the respondents in this study are middle-aged women.

Second, a further investigation of the impact of household cooking fuel switching on the health status of women from different groups found that: (1) women from two age groups benefit from clean cooking fuel switching, and the health effect of clean cooking fuel switching on women aged 46 and above is more significant than that on women aged 45 and below because the former are more vulnerable to household air pollution caused by solid fuel combustion; (2) the health effect of clean cooking fuel switching on women 
from rural areas is significant, while that on women from urban areas is insignificant or even negative because the process of household cooking fuel switching in rural areas falls behind that in urban areas in China; (3) uneducated women benefit more than educated women from clean cooking fuel switching; and (4) age, household income, hukou, marriage status, the number of the family member, whether smoking, and whether having insurance are all significant factors influencing the investigated women's health status.

Future research work should try to enlarge the scope and improve the results in two aspects. First, when health data is available, more specific health indicators should be adopted as proxies of women's health status relating to air pollution caused by solid fuel combustion, such as indicators relating to the respiratory system. The main explanation is that self-rated health and others-rated health employed in this study are comprehensive health indicators and may be influenced by plenty of factors. Second, more groups such as children and the elderly should be considered because they also spend a lot of time indoors and are vulnerable to household air pollution caused by solid fuel combustion. A comprehensive investigation of the impact of household cooking fuel switching on different groups helps make corresponding environmental and health policies.

Funding: This work was funded by the Philosophy and Social Science Planning Program of Zhejiang Province (NO. 22NDJC023Z); the Soft Science Research Program of Zhejiang Province (NO. 2021C35068).

Institutional Review Board Statement: Not applicable.

Informed Consent Statement: Not applicable.

Data Availability Statement: Not applicable.

Conflicts of Interest: The authors declare no conflict of interest.

\section{Appendix A}

Table A1. Questions for the measurement of IADL.

\begin{tabular}{ll}
\hline Variables & Questions \\
& Can you perform outdoor activities independently, such as walking about $300 \mathrm{~m}$ to \\
the station, shopping center, or parking lot? \\
Can you eat independently, such as making a cup of tea, breaking off steamed buns, \\
or picking dishes? \\
Can you perform independent kitchen activities such as preparing lunch for \\
1-2 people, setting the table, wiping the table after meals, and washing dishes? \\
Can you use public transport independently, such as taking trams, buses, trains, and \\
boats in your residential area, including going to and from the station, getting on \\
and off the bus, moving within the bus, buying tickets, and finding seats? \\
Can you shop independently, such as at local stores and shopping centers, including \\
shopping-related activities such as getting in and out of the mall, choosing goods, \\
paying for items, and taking them home? \\
Can you clean independently, such as making the bed, daily cleaning, mopping the \\
bathroom floor, vacuuming, changing sheets, cleaning windows, and taking out \\
the garbage? \\
Can you perform laundry independently, including washing sheets and clothes in \\
the laundry room or using your laundry equipment, sorting clothes, choosing \\
laundry procedures, operating the washing machine, putting and taking out clothes, \\
drying clothes, folding and organizing dry laundry?
\end{tabular}

Data source: The CFPS in 2014 and 2018.

\section{References}

1. IEA. World Energy Outlook 2019; International Energy Agency: Paris, France, 2019. Available online: https://www.iea.org/events/ world-energy-outlook-2019 (accessed on 12 September 2021).

2. Garba, I.; Bellingham, R. Energy poverty: Estimating the impact of solid cooking fuels on GDP per capita in developing countries-Case of sub-Saharan Africa. Energy 2021, 221, 119770. [CrossRef] 
3. Huang, W.; Baumgartner, J.; Zhang, Y.; Wang, Y.; Schauer, J.J. Source apportionment of air pollution exposures of rural Chinese women cooking with biomass fuels. Atmos. Environ. 2015, 104, 79-87. [CrossRef]

4. Barron, M.; Torero, M. Household electrification and indoor air pollution. J. Environ. Econ. Manage. 2017, 86, 81-92. [CrossRef]

5. Jagger, P.; Shively, G. Land use change, fuel use and respiratory health in Uganda. Energy Policy 2014, 67, 713-726. [CrossRef]

6. Yu, K.; Qiu, G.; Chan, K.H.; Lam, K.B.H.; Kurmi, O.P.; Bennett, D.A.; Yu, C.; Pan, A.; Lv, J.; Guo, Y.; et al. Association of solid fuel use with risk of cardiovascular and all-cause mortality in rural China. JAMA-J. Am. Med. Assoc. 2018, 319, 1351-1361. [CrossRef]

7. Lee, K.K.; Bing, R.; Kiang, J.; Bashir, S.; Spath, N.; Stelzle, D.; Mortimer, K.; Bularga, A.; Doudesis, D.; Joshi, S.S.; et al. Adverse health effects associated with household air pollution: A systematic review, meta-analysis, and burden estimation study. Lancet Glob. Health 2020, 8, 1427-1434. [CrossRef]

8. Balmes, J.R. Household air pollution from domestic combustion of solid fuels and health. J. Allergy Clin. Immunol. 2019, 143, 1979-1987. [CrossRef] [PubMed]

9. Imelda. Indoor air pollution and infant mortality: A new approach. AEA Pap. Proc. 2018, 108, 416-421. [CrossRef]

10. IEA. World Energy Outlook 2020; International Energy Agency: Paris, France, 2021. Available online: https://www.iea.org/ reports/world-energy-outlook-2020 (accessed on 12 September 2021).

11. UN. Five Reasons You Should Care About Air Pollution. UN Environ. Programme 2019. Available online: https://www.unep.org/ news-and-stories / story / five-reasons-you-should-care-about-air-pollution (accessed on 12 September 2021).

12. Yasmin, N.; Grundmann, P. Home-cooked energy transitions: Women empowerment and biogas-based cooking technology in Pakistan. Energy Policy 2020, 137, 111074. [CrossRef]

13. WHO. Household Air Pollution and Health; World Health Organization, 2018. Available online: https://www.who.int/news-room/ fact-sheets/detail/household-air-pollution-and-health (accessed on 12 September 2021).

14. WHO. WHO Guidelines for Indoor Air Quality: Household Fuel Combustion; World Health Organization, 2014. Available online: http:/ / europepmc.org/article/med/25577935 (accessed on 12 September 2021).

15. Rahut, D.B.; Ali, A.; Mottaleb, K.A. Understanding the determinants of alternate energy options for cooking in the Himalayas: Empirical evidence from the Himalayan region of Pakistan. J. Clean. Prod. 2017, 149, 528-539. [CrossRef]

16. Johnson, O.W.; Gerber, V.; Muhoza, C. Gender, culture and energy transitions in rural Africa. Energy Res. Soc. Sci. 2019, 49, 169-179. [CrossRef]

17. Oluwole, O.; Otaniyi, O.O.; Ana, G.A.; Olopade, C.O. Indoor air pollution from biomass fuels: A major health hazard in developing countries. J. Public Health 2012, 20, 565-575. [CrossRef]

18. Yasmin, N.; Grundmann, P. Adoption and diffusion of renewable energy-The case of biogas as alternative fuel for cooking in Pakistan. Renew. Sustain. Energy Rev. 2019, 101, 255-264. [CrossRef]

19. Choudhuri, P.; Desai, S. Gender inequalities and household fuel choice in India. J. Clean. Prod. 2020, 265, 121487. [CrossRef] [PubMed]

20. National Bureau of Statistics. Communiqué on major data of the third national agricultural census (No. 4). Natl. Bur. Statistics 2017. Available online: http:/ / www.stats.gov.cn/tjsj/tjgb/nypcgb/qgnypcgb/201712/t20171215_1563634.html (accessed on 12 September 2021).

21. Zhang, J.D.; Liu, W.J.; Xu, Y.S.; Cai, C.Y.; Liu, Y.; Tao, S.; Liu, W.X. Distribution characteristics of and personal exposure with polycyclic aromatic hydrocarbons and particulate matter in indoor and outdoor air of rural households in Northern China. Environ. Pollut. 2019, 255, 113176. [CrossRef]

22. Yun, X.; Shen, G.; Shen, H.; Meng, W.; Chen, Y.; Xu, H.; Ren, Y.; Zhong, Q.; Du, W.; Ma, J.; et al. Residential solid fuel emissions contribute significantly to air pollution and associated health impacts in China. Sci. Adv. 2020, 6, eaba7621. [CrossRef] [PubMed]

23. Fang, L.M.; Lu, N. Can the middle-aged and the elderly achieve their health improvement from domestic energy consumption structure optimization in rural China. China Popul. Resour. Environ. 2019, 29, 40-49.

24. Liu, Z.; Li, J.; Rommel, J.; Feng, S. Health impacts of cooking fuel choice in rural China. Energy Econ. 2020, 89, 104811. [CrossRef] [PubMed]

25. Song, D.Y.; Li, D.F. The improvement of rural household fuel structure and residents' health returns in China-Test based on CFPS data. J. Henan Univ. 2021, 61, 57-63.

26. Nie, P.; Sousa-Poza, A.; Xue, J. Fuel for life: Domestic cooking fuels and women's health in rural China. Int. J. Environ. Res. Public Health 2016, 13, 810. [CrossRef] [PubMed]

27. Gajate-Garrido, G. The impact of indoor air pollution on the incidence of life threatening respiratory illnesses: Evidence from young children in Peru. J. Dev. Stud. 2013, 49, 500-515. [CrossRef]

28. Fillenbaum, G.G. Screening the elderly: A brief instrumental activities of daily living measure. J. Am. Geriatr. Soc. 1985, 33, 698-706. [CrossRef] [PubMed]

29. Franks, P.; Gold, M.R.; Fiscella, K. Sociodemographics, self-rated health, and mortality in the US. Soc. Sci. Med. 2003, 56, 2505-2514. [CrossRef]

30. Tian, Z.; Tian, Y.; Shen, L.; Shao, S. The health effect of household cooking fuel choice in China: An urban-rural gap perspective. Technol. Forecast. Soc. Chang. 2021, 173, 121083. [CrossRef]

31. Demirbaş, A. Biomass resource facilities and biomass conversion processing for fuels and chemicals. Energy Convers. Manag. 2001, 42, 1357-1378. [CrossRef]

32. Hendryx, M.; Zullig, K.J.; Luo, J. Impacts of coal use on health. Annu. Rev. Public Health 2020, 41, 397-415. [CrossRef] 
33. Ali, M.U.; Yu, Y.; Yousaf, B.; Munir, M.A.M.; Ullah, S.; Zheng, C.; Kuang, X.; Wong, M.H. Health impacts of indoor air pollution from household solid fuel on children and women. J. Hazard. Mater. 2021, 416, 126127. [CrossRef]

34. Clark, M.L.; Peel, J.L.; Balakrishnan, K.; Breysse, P.N.; Chillrud, S.N.; Naeher, L.P.; Rodes, C.E.; Vette, A.F.; Balbus, J.M. Health and household air pollution from solid fuel use: The need for improved exposure assessment. Environ. Health Perspect. 2013, 121, 1120-1128. [CrossRef] [PubMed]

35. Afaj, A. IARC Monograph on the evaluation of carcinogenic risk to humans, volume 95: Household use of solid fuels and high-temperature frying. Int. J. Environ. Stud. 2011, 68, 252-253. [CrossRef]

36. Ni, K.; Carter, E.; Schauer, J.J.; Ezzati, M.; Zhang, Y.; Niu, H.; Lai, A.M.; Shan, M.; Wang, Y.; Yang, X.; et al. Seasonal variation in outdoor, indoor, and personal air pollution exposures of women using wood stoves in the Tibetan Plateau: Baseline assessment for an energy intervention study. Environ. Int. 2016, 94, 449-457. [CrossRef] [PubMed]

37. Chen, Y.; Shen, G.; Liu, W.; Du, W.; Su, S.; Duan, Y.; Lin, N.; Zhuo, S.; Wang, X.; Xing, B.; et al. Field measurement and estimate of gaseous and particle pollutant emissions from cooking and space heating processes in rural households, northern China. Atmos. Environ. 2016, 125, 265-271. [CrossRef]

38. Peng, L.; Zhang, Q.; Yao, Z.; Mauzerall, D.L.; Kang, S.; Du, Z.; Zheng, Y.; Xue, T.; He, K. Underreported coal in statistics: A survey-based solid fuel consumption and emission inventory for the rural residential sector in China. Appl. Energy 2019, 235, 1169-1182. [CrossRef]

39. Zhou, Y.; Zi, T.; Lang, J.; Huang, D.; Wei, P.; Chen, D.; Cheng, S. Impact of rural residential coal combustion on air pollution in Shandong, China. Chemosphere 2020, 260, 127517. [CrossRef]

40. Gu, Y.; Zhang, W.; Yang, Y.; Wang, C.; Streets, D.G.; Yim, S.H.L. Assessing outdoor air quality and public health impact attributable to residential black carbon emissions in rural China. Resour. Conserv. Recycl. 2020, 159, 104812. [CrossRef]

41. Du, W.; Li, X.; Chen, Y.; Shen, G. Household air pollution and personal exposure to air pollutants in rural China-A review. Environ. Pollut. 2018, 237, 625-638. [CrossRef]

42. Smith, K.R.; Uma, R.; Kishore, V.V.N.; Zhang, J.; Joshi, V.; Khalil, M.A.K. Greenhouse implications of household stoves: An analysis for India. Annu. Rev. Energy Environ. 2000, 25, 741-763. [CrossRef]

43. Zhang, J.; Smith, K.R.; Ma, Y.; Ye, S.; Jiang, F.; Qi, W.; Liu, P.; Khalil, M.A.K.; Rasmussen, R.A.; Thorneloe, S.A. Greenhouse gases and other airborne pollutants from household stoves in China: A database for emission factors. Atmos. Environ. 2000, 34, 4537-4549. [CrossRef]

44. Díaz, E.; Smith-Sivertsen, T.; Pope, D.; Lie, R.T.; Díaz, A.; McCracken, J.; Bakke, P.; Arana, B.; Smith, K.R.; Bruce, N. Effect of reducing indoor air pollution on women's respiratory symptoms and lung function: The RESPIRE Randomized Trial, Guatemala. Am. J. Epidemiol. 2009, 170, 211-220. [CrossRef]

45. Zhang, W.; Li, A.; Xu, Y.; Liu, J. The theory-practice gap of black carbon mitigation technologies in rural China. Atmos. Environ. 2018, 174, 122-131. [CrossRef]

46. Pokhrel, A.K.; Smith, K.R.; Khalakdina, A.; Deuja, A.; Bates, M.N. Case-control study of indoor cooking smoke exposure and cataract in Nepal and India. Int. J. Epidemiol. 2005, 34, 702-708. [CrossRef]

47. Zhang, J.; Smith, K.R. Household air pollution from coal and biomass fuels in China: Measurements, health impacts, and interventions. Environ. Health Perspect. 2007, 115, 848-855. [CrossRef]

48. Sapkota, A.; Gajalakshmi, V.; Jetly, D.H.; Roychowdhury, S.; Dikshit, R.P.; Brennan, P.; Hashibe, M.; Boffetta, P. Indoor air pollution from solid fuels and risk of hypopharyngeal/laryngeal and lung cancers: A multicentric case-Control study from India. Int. J. Epidemiol. 2008, 37, 321-328. [CrossRef]

49. Baumgartner, J.; Schauer, J.J.; Ezzati, M.; Lu, L.; Cheng, C.; Patz, J.A.; Bautista, L.E. Indoor air pollution and blood pressure in adult women living in rural China. Environ. Health Perspect. 2011, 119, 1390-1395. [CrossRef] [PubMed]

50. Epstein, M.B.; Bates, M.N.; Arora, N.K.; Balakrishnan, K.; Jack, D.W.; Smith, K.R. Household fuels, low birth weight, and neonatal death in India: The separate impacts of biomass, kerosene, and coal. Int. J. Hyg. Environ. Health 2013, 216, 523-532. [CrossRef] [PubMed]

51. Pang, J.; Wu, J.; Ma, Z.; Liang, L.N.; Zhang, T.T. Air pollution abatement effects of replacing coal with natural gas for central heating in cities of China. China Environ. Sci. 2015, 35, 80-92.

52. Tang, Y.; Liang, R.B. Does energy substitution improve air quality: Analysis from energy pricing mechanism. China Popul. Resour. Environ. 2018, 28, 80-92. (In Chinese)

53. Zhang, Y.; Li, W.; Wu, F. Does energy transition improve air quality? Evidence derived from China's Winter Clean Heating Pilot (WCHP) project. Energy 2020, 206, 118130. [CrossRef]

54. Ellegård, A. Cooking fuel smoke and respiratory symptoms among women in low-income areas in Maputo. Environ. Health Perspect. 1996, 104, 980-985. [CrossRef] [PubMed]

55. Balakrishnan, K.; Parikh, J.; Sankar, S.; Padmavathi, R.; Srividya, K.; Venugopal, V.; Prasad, S.; Pandey, V.L. Daily average exposures to respirable particulate matter from combustion of biomass fuels in rural households of Southern India. Environ. Health Perspect. 2002, 110, 1069-1075. [CrossRef]

56. Wang, Y.; Chen, X.; Ren, S. Clean energy adoption and maternal health: Evidence from China. Energy Econ. 2019, 84, 104517. [CrossRef]

57. Cesur, R.; Tekin, E.; Ulker, A. Can natural gas save lives? Evidence from the deployment of a fuel delivery system in a developing country. J. Health Econ. 2018, 59, 420-427. [CrossRef] [PubMed] 
58. Kim, C.; Seow, W.J.; Shu, X.O.; Bassig, B.A.; Rothman, N.; Chen, B.E.; Xiang, Y.B.; Hosgood, H.D.; Ji, B.T.; Hu, W.; et al. Cooking coal use and all-cause and cause-specific mortality in a prospective cohort study of women in Shanghai, China. Environ. Health Perspect. 2016, 124, 1384-1389. [CrossRef]

59. Fang, L.M.; Liu, H.B. Solid fuels utilization, health equity and energy poverty alleviation in rural China. J. Agrotech. Econ. 2019, 7, 115-125. (In Chinese)

60. Liao, H.; Tang, X.; Wei, Y.M. Solid fuel use in rural China and its health effects. Renew. Sustain. Energy Rev. 2016, 60, 900-908. [CrossRef]

61. Liu, J.; Hou, B.; Ma, X.W.; Liao, H. Solid fuel use for cooking and its health effects on the elderly in rural China. Environ. Sci. Pollut. Res. 2018, 25, 3669-3680. [CrossRef] [PubMed]

62. Greenstone, M.; Jack, B.K. Envirodevonomics: A research agenda for an emerging field. J. Econ. Lit. 2015, 53, 5-42. [CrossRef]

63. Li, Q.; Jiang, J.; Wang, S.; Rumchev, K.; Mead-Hunter, R.; Morawska, L.; Hao, J. Impacts of household coal and biomass combustion on indoor and ambient air quality in China: Current status and implication. Sci. Total Environ. 2017, 576, 347-361. [CrossRef]

64. Ning, M.; Gong, J.; Zheng, X.; Zhuang, J. Does new rural pension scheme decrease elderly labor supply? Evidence from CHARLS. China Econ. Rev. 2016, 41, 315-330. [CrossRef]

65. Arku, R.E.; Brauer, M.; Duong, M.L.; Wei, L.; Hu, B.; Ah Tse, L.; Mony, P.K.; Lakshmi, P.V.M.; Pillai, R.K.; Mohan, V.; et al. Adverse health impacts of cooking with kerosene: A multi-country analysis within the prospective urban and rural epidemiology study. Environ. Res. 2020, 188, 109851. [CrossRef] [PubMed]

66. Chattopadhyay, M.; Arimura, T.H.; Katayama, H.; Sakudo, M.; Yokoo, H.F. Subjective probabilistic expectations, household air pollution, and health: Evidence from cooking fuel use patterns in West Bengal, India. Resour. Energy Econ. 2021, 66, 101262. [CrossRef]

67. Saenz, J.L.; Adar, S.D.; Zhang, Y.S.; Wilkens, J.; Chattopadhyay, A.; Lee, J.; Wong, R. Household use of polluting cooking fuels and late-life cognitive function: A harmonized analysis of India, Mexico, and China. Environ. Int. 2021, 156, 106722. [CrossRef]

68. Han, H.; Wu, S.; Zhang, Z. Factors underlying rural household energy transition: A case study of China. Energy Policy 2018, 114, 234-244. [CrossRef]

69. Dilmaghani, M. The causal effects of education on health over the life course: Evidence from Canada. Public Health 2020, 186, 170-177. [CrossRef] [PubMed]

70. Alem, Y.; Beyene, A.D.; Köhlin, G.; Mekonnen, A. Modeling household cooking fuel choice: A panel multinomial logit approach. Energy Econ. 2016, 59, 129-137. [CrossRef]

71. Chan, K.W.; Buckingham, W. Is China abolishing the hukou system? China Q. 2008, 195, 582-606. [CrossRef]

72. Pan, J.; Lei, X.Y.; Liu, G.E. Does health insurance lead to better health? Econ. Res. J. 2013, 4, 140-142. (In Chinese)

73. Bandyopadhyay, S.; Shyamsundar, P.; Baccini, A. Forests, biomass use and poverty in Malawi. Ecol. Econ. 2011, 70, $2461-2471$. [CrossRef]

74. Hsiao, C. Analysis of Panel Data; Cambridge University Press: Cambridge, UK, 2003.

75. CFPS. CFPS Public Data. China Family Panel Studies. Available online: http://www.isss.pku.edu.cn/cfps/en/data/public/ index.htm (accessed on 12 September 2021).

76. Chen, Q. Advanced Econometrics and Stata Applications; Higher Education Press: Beijing, China, 2014. (In Chinese)

77. Luo, R.R.; Dai, H.X.; Zhang, Y.H.; Qiao, L.P.; Ma, Y.G.; Zhou, M.; Xia, B.; Zhu, Q.Y.; Zhao, Y.Y.; Huang, C. Exposure levels, sources, and health risks of heavy metal components of $\mathrm{PM}_{2.5}$ in housewives in rural Shanghai. Environ. Sci. 2019, 40, 5224-5233. (In Chinese)

78. Zhai, S.G. Collaborative governance of health poverty: Logic, experience, and path. Gov. Stud. 2018, 34, 53-60. (In Chinese)

79. Li, Y.; Li, M.Q. A study on health poverty vulnerability and its influencing factors of rural females in China. J. Hubei Minzu Univ. 2021, 39, 105-118. (In Chinese)

80. Malakar, Y.; Greig, C.; van de Fliert, E. Resistance in rejecting solid fuels: Beyond availability and adoption in the structural dominations of cooking practices in rural India. Energy Res. Soc. Sci. 2018, 46, 225-235. [CrossRef]

81. Tao, S.; Ru, M.Y.; Du, W.; Zhong, Q.R.; Li, B.G.; Shen, G.F.; Pan, X.L.; Meng, W.J.; Chen, Y.L.; She, H.Z.; et al. Quantifying the rural residential energy transition in China from 1992 to 2012 through a representative national survey. Nat. Energy 2018, 3, 567-573. [CrossRef]

82. Wu, S.M.; Zheng, X.Y.; You, C.Y.; Wei, C. Household energy consumption in rural China: Historical development, present pattern and policy implication. J. Clean. Prod. 2019, 221, 981-991. [CrossRef]

83. Han, H.; Wu, S. Rural residential energy transition and energy consumption intensity in China. Energy Econ. 2018, 74, 523-534. [CrossRef] 